\section{Georges Cuvier}

Zoologist-a Study in the History of Evolution Theory. By William Coleman. Pp. $x+212$. (Cambridge, Mass. Harvard University Press; London: Oxford University Press, 1964.) 40s. net.

$\mathrm{T}$ HE life of Cuvier is a 'success' story, a rise from provincial obscurity to eminence as an imperia inspector of public instruction under Napoleon and peer of the realm under the restored Bourbons. It is also a record of sustained, highly organized and immensely productive enquiry into the structure of animals. "Dissection and description," in the words of Mr. Coleman, "could produce the clear and indisputable facts, and comparison could generalize them and reveal their real significance. The principal generalizations thus formed were the famous anatomical rules: the correlation of parts, which established the interrelated physiological operations and morphological features which guaranteed the life and integrity of the organism, and the subordination of characters, which determined the taxonomic value of the structures making up the organism."

After Aristotle, whom he held in profound respect and whose teleological attitude he endorsed, Cuvier is the supreme comparative anatomist. His contributions to classification (as distinct from taxonomy) are profound; the principles underlying the modern subdivisions of the animal kingdom spring directly from the criteria on which ho based establishment of his four embranchements. Belief in special creation, based on scientific rather than religious belief, did not prevent investigation of fossils, to the reconstruction of which he applied the pregnant conception of the correlation of parts. The first true palæontologist, he nowhere contemplated a succession of species with extinct forms providing evidence of progressive advance. $\mathrm{H}_{e}$ thought only of a series of populations successively eliminated by catastrophes.

Opposing with equal vigour the evolutionary ideas of Lamarck and the concept of the archetype propounded by the German Naturphilosophen and so ardently championed by his other great contemporary, Etienne Geoffroy St. Hilaire, Cuvier has more in common with Linnaeus. Both sought, the latter in the Systema Naturae and the former in the Régne animal, to lay bare the plan of creation. Failing inevitably in this, they nevertheless, by establishment of the species concept and by clear demonstration of structural relationships, laid firm foundations for later establishment of the fact of evolution.

In this concisely written book, Mr. Coleman has not attempted a life of Cuvier with its public triumphs and private tragedies. He confines himself to an analysis of ideas contained in Cuvier's unpublished as well as his published work, and in so doing provides an important contribution to the history of zoological thought.

C. M. YoNge

Iconographia Mycologica, VIII

By $O$. Verona and $T$. Benedek. (Mycopathologia et Mycologia Applicata, Vol. XVIII, Supplementum.) Pp. iv + plates $A$ 166-181, B52-65, C106-115, D30-39. (Den Haag: Uitgeverij Dr. W. Junk, 1962.) n.p.

Iconographia Mycologica, IX

By O. Verona and T. Benedek. (Mycopathologia et Mycologia Applicata, Vol. XIX, Supplementum.) Pp. iv + plates $A 182-203, B 66-73, C 116-135$. (Den Haag: Uitgeverij Dr. W. Junk, 1963.) n.p.

Iconograshia Mycologica, $\mathrm{X}$

By O. Verona and T. Benedek. (Mycopathologia et Mycologia Applicata, Vol. XX, Supplementum.) (Den Haag: Uitgeverij Dr. W. Junk, 1963.) n.p.

THIS series of unbound plates, 50 to a volume, offers clear line drawings to illustrate the genera of microfungi. Usually only one species is figured, occasionally a small genus is treated in greater detail; for Fusoma Corda, Plate A169, no species is named, though conidia and conidiophores are drawn.

The scope of the work is very wide, covering every group of fungi from the lower Phycomycetes to the Uredinales, a field too vast for any modern specialist. Hence, in the chrotic state of fungus systematics, the authors must expect serious problems in the interpretation and typification of some generic names. They are not well-known taxonomic mycologists, and their work would have greater authority if the source of each plate were elearly stated. At present one is left to guess how much is original, how much copied and from which source. When, as with Englerulaster macowanianus (Plate C114), for example, a figure is attributed to a standard authority, it may be found to have been somewhat drastically redrawn. This plate is taken from Arnaud, but that next to it, Morenoella mollinediae (C113), is not clearly so attributed. though he is cited as authority for the genus. Comparison with Arnaud's Pl. XXI shows the lower part of $C 113$ to be copied closely from his work and the remaining portions to be apparently inspired by him, but they are so modified that direct borrowing cannot be demonstrated.

A brief deseription accompanies each plate. The book is in English, sometimes not happily worded, and the proof-reading leaves something to be desired. For example, on p. D38 we read: "Schizonella parasitizes Ciferaceae" and, under Cintractia, "living on Ciperaceae"; in each case 'Cyperaceae' is intended. This would appear to be a work which could fill a useful role for mycologists who lack access to an adequate library, but which would profit by more critical taxonomic supervision.

R. W. G. Dennis

The Annual Species of Medicago

By Chaia Clara Heyn. (Scripta Hierosolymitana, Vol. 12.) Pp. 154. (Jerusalem: At the Magnes Press, The Hebrew University; London: Oxford University Press, 1963.) 36s. net.

COME genera seem to have been designed by Nature to $\checkmark$ defeat the plans of botanists; somo re-planned by botanists to obscure the designs of Nature. Medicago has had the worst of both worlds, the natural intricacies of its taxonomy being further confused by the complexities of its nomenclature. Fortunately Dr. Heyn has appeared, like a botanical Ariadne, offering guidance through the labyrinth, and showing us that the way, though tortuous onough, is not insuperably perplexing.

The revision is restricted to the annual members of the genus, and includes full descriptions and synonymy of 28 species and 35 varieties, supplomented by keys and a generous number of really excellent illustrations, photographs and text diagrams. Notes on habitat and geographical distribution, and lists of specimens examined, accompany the description of each species and variety, and where the author feels the need for furthor elucidation there are explanatory notes on taxonomy and nomenclature. All this information, together with a readable introduction and a good bibliography, will como as a boon, not only to professional taxonomists, but to all those agriculturists and plant-broeders who have hitherto struggled with this intractable gonus.

Dr. Heyn has had the good luck to live in a country whore it is possible to examine living spocimens of most of tho species she describes; it is gratifying to add that she has taken full advantage of hor situation, and provided us with a revision which will be of lasting value. Only very occasionally, as in the treatment of Medicago aculeata and its varieties, or in the comments on the typification of the genus Medicago, does one venture to question her conclusions, and, in such a labyrinth, it would surely be unreasonable to expect that our guide should never once falter or stumble.
R. D. MeIKLe 